\title{
Dental health in sickle cell disease
}

\author{
S. M. AlDallal ${ }^{1 *}$, M. M. AlKathemi ${ }^{2}$, W. H. Haj ${ }^{3}$ and N. M. AlDallal ${ }^{4}$ \\ ${ }^{1}$ Haematology Laboratory Specialist, Amiri Hospital, Kuwait \\ ${ }^{2}$ Dentist, General Practitioner, Dental One Clinic, Kuwait \\ ${ }^{3}$ Paediatric \& Handicapped Dental Specialist, Basma Clinic, Kuwait \\ ${ }^{4}$ General Surgeon, Farwaniya Hospital, Kuwait
}

\begin{abstract}
Sickle cell disease (SCD) is one of the most common blood disorders typically inherited from one's parents. It is presented with a wide variety of clinical symptoms, and varied degrees of severity that can be determined based on the phase during which the disease is diagnosed, the age of the patient, number of hospitalisations in the past, requirement for continuous drug use and for blood transfusions, in addition to several other factors. It is highly critical that the physicians should be aware of the oral manifestations and physiopathology of the disease. Additionally, the dental surgeons should cautiously obtain the patient's clinical history and collect information about specific features so that they can build up a plan for any dental treatment that is in accordance to the patient's limitations and requirements. Maintaining a complete chart recording the general patient information along with periodically updating the medical history of the patient should be practise by all the physicians. The treatment strategy should focus on the achievement and maintenance of oral health and to decrease the risks of dental complications. The literature summarizes the treatment of dental complications in patients with SCD.
\end{abstract}

\section{Introduction}

Sickle cell disease (SCD) is one of the most prevalent genetic disorders worldwide. Studies have reported a count of approximately 100,000 Americans being affected by this disease. It is also estimated that one in 500 US African American births is affected with sickle cell anaemia. The prevalence of the disease is highest in sub-Saharan Africa and is also widely spread through Middle East, Southeast Asia, and Mediterranean regions [1]. Around 5-7\% of the population worldwide carries an abnormal haemoglobin gene with the frequency of SCD noted as one in four in every 50 West Africans and making itself the commonest genetic disease in UK and France [2,3]. SCD is the most prevailing form of hemoglobinopathy. The disease is characterized by morphologic changes in red blood cells (RBCs), triggered by abnormal haemoglobin $(\mathrm{Hb})$ polymerization. The sickle mutation is the consequence of single base change, GAG to GTG, in the sixth codon of exon 1 of the $\beta$-globin gene in charge for the synthesis of the $\beta$-globin polypeptide of the $\mathrm{Hb}$ molecule ( $\alpha 2 \beta 2$ ). This change cause substitute of the normal glutamic acid with valine at position 6 of the $\beta$-globin chain and the development of sickle $\mathrm{Hb}(\beta \mathrm{s} \beta \mathrm{s})$ [4-6]. Acute infections can activate sickle cell crises. Therefore, it is imperative that dental infections should be prevented but, if there is an occurrence of infection, then effective ways of dealing with it should be devised immediately. A clear understanding of the dental implications of SCA must be gained in order to successfully treat SCA patients. The treatment should always begin only after a thorough investigation on the patient's background has been performed.

\section{Clinical presentation of SCD}

The signs and symptoms of SCD vary from one patient to the other and may change over time. A key aspect of the disease is vaso-occlusive crises of the microcirculation, which leads to inadequate blood supply to tissues and consequently results in tissue necrosis [7]. Pain is the main and the most chronic feature of this disease and dominates its clinical representation throughout the life of the patient. Patients frequently report pain in form of acute pain crises. It has a substantial impact on the quality of life of the patient and their families. Therefore, several medical and psychological treatment techniques are widely devised and used for pain management in patients affected with SCD $[8,9]$.

In SCD, all body organs are affected or remain at the constant risk of being affected. As such, the most prevalent complications include diseases of nervous, cardiopulmonary, musculoskeletal, hepatobiliary, endocrine and genitourinary systems [10]. The most frequent oral manifestations of SCD greatly affect the oral mucosa, gingival tissue, mandible, osteonecrosis, facial swelling, increased risks for caries nerve supply, and tooth enamel and pulp [11-19] (Table 1). In addition, paleness of the oral mucosa, delayed tooth eruption, depapillation leading to atrophic alteration of the tongue, high degree of abnormality in the hypophosphatemic teeth, odontogenic infection, orofacial pain, craniofacial disorders such as protrusion of the midface area, maxillary expansion, mandibular retrusion, and maxillary protrusion. Dentists play a significant role in avoiding these complications and improving the quality of life in SCD patients as the SCD patients are more vulnerable to infections and periodontal disease [20,21]. Furthermore, these patients are at a higher risk of developing dental caries leading to elevated occurrence of dental opacities arising due to the unremitting

Correspondence to: S. M. AlDallal, Haematology Laboratory Specialist; Amiri Hospital, Kuwait, Tel: +965-90981981; Fax: +965-22463790; E-mail: dr.s.aldallal@outlook.com

Key words: sickle cell disease, dental care, dental complications, caries, infection, malocclusion

Received: January 06, 2017; Accepted: January 27, 2017; Published: January 30, 2017 
Table 1. Dental complications of SCD [9].

\begin{tabular}{|l|}
\hline \multicolumn{1}{|c|}{ Dental Complications of SCD } \\
\hline Dental Caries \\
\hline Infractions \\
\hline Hypodontia \\
\hline Dental Erosions \\
\hline Malocclusions \\
\hline Pulp Necrosis \\
\hline Abnormal Trabecular Spacing \\
\hline Infection \\
\hline
\end{tabular}

use of medication containing sucrose owing to the high incidence of complications and hospitalization required by the lack of proper oral cleanliness [22]. Managing dental complications is frequently ignored as SCD patients are more dedicated towards maintaining a standard general health because of the serious blood disorder. Ignoring minor dental health matters under these conditions not only worsen the problem but can also cause a painful sickle-cell crisis, leading to emergency hospital admission. Therefore, the management of oral complications in SCD patients require to be modified in accordance to their blood disorder, in order not to cause any additional deterioration to their overall health.

\section{Dental complications in SCD}

The dental complications in sickle cell anaemia must be understood at first to efficiently treat SCD patients. The management and treatment of the patients should begin with a thorough assessment of the patient's background. Studies have revealed that common oral findings associated with the disorder include mucosal pallor, dental hypoplasia, delayed eruption, and radiographic changes [23]. Furthermore, hypercementosis, which leads to excessive generation of normal calcified tissue on the roots of one or more teeth, has also been reported in SCD patients [24]. Malocclusion of the teeth, intrinsic opacity of enamel, dental caries, and diastemata are other dental remarks found in the disease in sicklers [25]. Details on some of these are described below.

\section{Dental caries}

Dental caries are the most frequent dental complication worldwide. Patients with SCD are more susceptible to dental caries having more chances of tooth decay [26]. Caries is identified as an infectious disease of teeth causing progressive demineralization and destruction of the enamel, dentin, and cementum of the teeth [9]. The key source of caries is the acidification of the oral environment, which is caused by the fermentation of remaining food particles mainly sugars or carbohydrates on tooth surfaces [27]. Untreated caries can cause slow destruction and tooth fractures. It may also further lead to infection of the surrounding oral soft tissues and may also transfer to ear, neck and jaw [28] Sometimes, it may be as fatal as causing cavernous sinus thrombosis (CST) leading to the blood clot in the cavernous sinus, the reason being complication of an infection in teeth [29].

SCD patients appear to be more vulnerable to dental caries than healthy people. Also, the occurrence of caries in SCD children and adults are known to associated with the socioeconomic status of the affected families [22-30]. Low income most frequently affects the amount of value given on lifestyle, health and access to medical care and health information. Past results have shown that low-income individuals are more susceptible to decayed teeth problems as compared with individuals without the disease On the other hand, Passos et al.
[31] reported that the disease itself does not particularly predispose to caries or periodontal disease. Risk the contributing factors including daily smoking, older age, and lack of daily dental flossing can attributed towards dental caries and periodontal diseases.

\section{Hypodontia}

Hypodontia, also known as tooth agenesis, refers to missing teeth as a result of failure for them to develop. It has been described in one patient with HbSC disease [32]. These patients must be subjected to preventive care to lessen the chances of any functional complications.

\section{Dental erosion}

Dental Erosions, also known as acid erosions, result from acidity that is not caused by bacteria but by food particularly acidic fruit juices. Intrinsic causes of acidity comprise certain disorders such as gastroesophageal reflux where gastric acid is in contact with teeth. Erosions have not been described in SCD patients [33,34].

\section{Malocclusion}

Malocclusion, in dentistry, refers to the manner opposing teeth meet. The father of modern orthodontics, Edward Angle, introduced the term malocclusion which is defined as a misalignment of the teeth between the two corresponding dental arches (Figure 1A) [35]. He divided malocclusion into three classes in accordance to the severity and the relation between the teeth involved. In Class I, the occlusion in a SS patient is normal for the first maxillary molar but abnormal for the other teeth with crowding, rotation, and spacing and over or under eruption (Figure 1B). In Class II, inconsistent jaw growth is observed in a patient with HbSS whereas the lower jaw is deficient in forward growth causing an overjet $>3 \mathrm{~mm}$ (Figure 1C). This increases the chances of dental trauma as compared to those with an overjet $<3 \mathrm{~mm}$ In Class III, malocclusion in a patient with HbSS, it has been observed that the lower jaw extends too far forward ahead of the upper jaw causing an under-bite, which is also known as mandibular prognathism (Figure 1D) [36]. Reports have shown that Class II malocclusion was most frequent in SCD patients [9]. Furthermore, facial growth alterations which are frequent in SCD might also result in malocclusion because of protrusive maxilla and forward growth tendency of the mandible $[37,38]$.

Malocclusion can be corrected by the application of braces to the protruding teeth. The braces are metallic or ceramic sets of wire that are cemented to the teeth for 2-3 years or a particular time period as stated by the orthodontists [9]. It is advised that the braces procedure and treatments must be done at childhood stage in order to avoid speech problem and bite issues. It should be noted that when a SCD affected patient is undergoing orthodontic treatment, the practitioner be completely aware of the disease and the respective treatment procedure as a complete blood supply is highly important during and after the application of intraoral and extraoral forces. The orthodontist should be very careful about the chances of pulpal necrosis involving healthy teeth, the alterations in the bone turnover during orthodontic movements, the mandibular painful episodes, and the increased susceptibility to infections during the treatment.

\section{Infection}

Poor dental cleanliness can lead to tooth decay or cavities and also results in to the formation of plaque on teeth when food particles interact with bacteria normally found in the mouth. Plaque that remains on the teeth for a long time hardens and forms calculus. The 


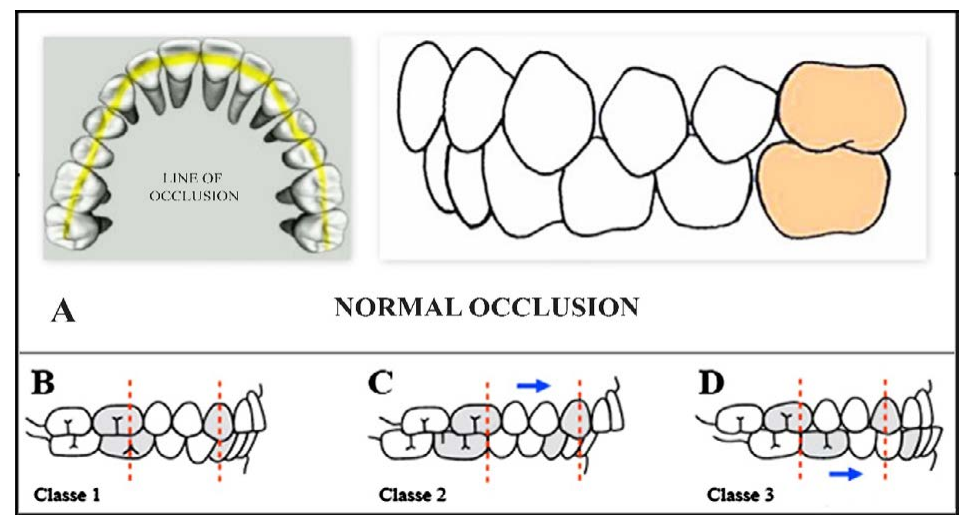

Figure 1. Classification of dental malocclusion. (A) Normal occlusion: The cup of the maxillary first molar is aligned with the buccal groove of the mandibular first molar. There is alignment of the teeth, normal overbite and overjet and maxillary and mandibular midlines. (B) Class I malocclusion: A normal molar relationship exists but there is crowding, misalignment of the teeth, cross bites, etc. (3) Class II malocclusion: Has two divisions to describe the position of the anterior teeth; division 1: is when the maxillary anterior teeth are proclined and a large over jet is present; division 2: is where the maxillary anterior teeth are retroclined and a deep overbite exists. (D) Class III malocclusion: A malocclusion where the molar relationship shows the buccal groove of the mandibular first molar distally positioned when in occlusion with the mesiobuccal cusp of the maxillary first molar (Adapted from Dental Photographs, 2015) [39].

formation of plaque and the associated bacteria can not only lead to infection in the gums and teeth, but also affect the gum tissue and bone that support the teeth. Persistent plaque and calculus cause also gingivitis, thereby leading to inflammation of the gums and bleeding. If proper treatment is not adopted, gingivitis can proceed to have serious complications such as chronic peritonitis, dental abscess, and bone destruction culminating in tooth loss [40]. Periodontal infection may precipitate painful vaso-occlusive crises and increase the frequency of hospital admissions among adult SCD patients [41,42].

\section{Pulp necrosis}

Pulp necrosis, or dead pulp, is defined as necrotic dental pulp due to infection, trauma or chemical reaction characterized by no response to thermal stimulation. A necrotic dental pulp causes toothache, acute apical periodicities, discoloration of the tooth or dental abscess [43]. Previous reports suggest that HbSS is a potential risk factor for pulp necrosis in intact permanent teeth $[44,45]$. A reduced blood supply to teeth results in necrosis of the dental pulp in patients with SCD. Such abnormal blood flow to the dental pulp might result in increased toothaches in SCD patents. Javed et al. have also stated that there are also chances that a certain proportion of SCD patients may remain asymptomatic to pulp changes, which may make them unsuspecting of the ongoing dental pulp tissue damage.

\section{Conclusion}

This mini review was designed to present brief background information on SCD, and describing the course of oral complications in SCD patients. The dentist's aim should be to treat the SCD patient with a thorough understanding and knowledge of the disorder and the consequences of the disease must be considered carefully before dental treatment is started. One of the dentist's goals should be to instil a positive attitude in the SCD patient and their parents toward maintaining good dental health. In addition, it is always advisable that sickle-cell anaemia carriers should be encouraged to have their oral health under control by practicing preventive procedures as directed by the physicians.

\section{Conflicts of interest}

None to be declared.

\section{Acknowledgments}

The authors are thankful to www.manuscriptedit.com for providing English language editing and proofreading services for this manuscript.

\section{References}

1. Serjeant GR (1997) Sickle-cell disease. Lancet 350: 725-730. [Crossref]

2. Modell B, Darlison M (2008) Global epidemiology of haemoglobin disorders and derived service indicators. Bull World Health Organ 86:480-487. [Crossref]

3. World Health Organization (2007) Management of haemoglobin disorders, in Proceedings of the report of joint WHO-TIF meeting. Nicosia, Cyprus.

4. Ingram VM (1956) A specific chemical difference between the globins of normal human and sickle-cell anaemia haemoglobin. Nature 178:729-794. [Crossref]

5. Ingram VM (1959) Abnormal human haemoglobins III. The chemical difference between normal and sickle cell haemoglobins. Biochim Biophys Acta 36:402-411. [Crossref]

6. Ingram VM (1957) Gene mutations in human haemoglobin: the chemical difference between normal and sickle cell haemoglobin. Nature 180: 326-328. [Crossref]

7. Steinberg MH (1998) Pathophysiology of sickle cell disease. Baillieres Clin Haematol 11: 163-184. [Crossref]

8. Serjeant GR (1993) The clinical features of sickle cell disease. Baillieres Clin Haematol 6: 93-115. [Crossref]

9. Ballas SK, Lobo CLDC, Cavalcanti WE (2014) Dental complications of sickle cell disease. J Interdisciple Med Dent Sci 2: 152.

10. Ballas S (2014) Sickle cell pain (2nd Ed.). Washington, USA: International Association of the Study of Pain.

11. Andrews CH, England MC Jr, Kemp WB (1983) Sickle cell anemia: an etiological factor in pulpal necrosis. $J$ Endod9: 249-252. [Crossref]

12. Bishop K, Briggs P, Kelleher M (1995) Sickle cell disease: a diagnostic dilemma. IntEndod J 28: 297-302. [Crossref]

13. Borle RM, Prasant MC, Badjate SJ, Patel IA (2001) Sickle cell osteomyelitis of the maxilla: a case report. J Oral Maxillofac Surg 59: 1371-1373. [Crossref]

14. DemirbaÅŸ Kaya A, Aktener BO, Unsal C (2004) Pulpal necrosis with sickle cell anaemia. Int Endod J 37: 602-606. [Crossref]

15. Ramakrishna Y (2007) Dental considerations in the management of children suffering from sickle cell disease: a case report. J Indian SocPedod Prev Dent 25: 140-143. [Crossref]

16. Singh J, Singh N, Kumar A, Kedia NB, Agarwal A (2013) Dental and periodontal health status of Beta thalassemia major and sickle cell anemia patients: a comparative study. $J$ Int Oral Health 5: 53-58. [Crossref]

17. Scipio JE, Al-Bayaty HF, Murti PR, Matthews R (2001) Facial swelling and gingival enlargement in a patient with sickle cell disease. Oral Dis 7: 306-309. [Crossref] 
18. Kelleher M, Bishop K, Briggs P (1996) Oral complications associated with sickle cell anemia: a review and case report. Oral Surg Oral Med Oral Pathol Oral Radiol Endod 82: 225-228. [Crossref]

19. Laurence B, George D, Woods D, Shosanya A, Katz RV, et al. (2006) The association between sickle cell disease and dental caries in African Americans. Spec Care Dentist 26: 95-100. [Crossref]

20. da Fonseca M, Oueis HS, Casamassimo PS (2007) Sickle cell anemia: a review for the pediatric dentist. Pediatr Dent 29: 159-169. [Crossref]

21. Taylor LB, Nowak AJ, Giller RH, Casamassimo PS (1995) Sickle cell anemia: a review of the dental concerns and a retrospective study of dental and bony changes. Spec Care Dentist 15: 38-42. [Crossref]

22. Luna AC1 Rodrigues MJ, Menezes VA, Marques KM, Santos FA (2012) Caries prevalence and socioeconomic factors in children with sickle cell anemia. Braz Oral Res 26: 43-49. [Crossref]

23. Cox GM, Soni NN (1984) Pathological effects of sickle cell anemia on the pulp. ASDC $J$ Dent Child 51: 128-132. [Crossref]

24. Soni NN (1966) Microradiographic study of dental tissues in sickle-cell anaemia. Arch Oral Biol 11: 561-564. [Crossref]

25. Okafor LA, Nonnoo DC, Ojehanon PI, Aikhionbare O (1986) Oral and denta complications of sickle cell disease in Nigerians. Angiology 37: 672-675. [Crossref]

26. Helaly M, Abuaffan A (2015) Association between sickle cell disease and dental caries among Sudanes children. J MolImag Dynamics 5: 120.

27. Ozdemir D (2013) Dental caries: the most common disease worldwide and preventive strategies. Int J Biol 5:55-61.

28. Wetherell J, Richards L, Smabrook P, Towns G (2001) Management of acute dental pain: a practicleapproch for primary health care providers. AustPrescr 24:144-148.

29. Yeo GS, Kim HY1, Kwak EJ1, Jung YS1, Park HS1, et al. (2014) Cavernous sinus thrombosis caused by a dental infection: a case report. J Korean Assoc Oral Maxillofac Surg 40: 195-198. [Crossref]

30. Laurence B, George D, Woods D, Shosanya A, Katz RV, et al. (2006) The association between sickle cell disease and dental caries in African Americans. Spec Care Dentist 26: 95-100. [Crossref]

31. Passos CP, Santos PR, Aguiar MC, Cangussu MC, Toralles MB, et al. (2012) Sickle cell disease does not predispose to caries or periodontal disease. Spec Care Dentist 32: 55-60. [Crossref]
32. Oredugba FA (2005) Hypodontia in an adolescent with the HbSC genotype: a case report. Int J Paediatr Dent 15: 455-458. [Crossref]

33. Dugmore CR, Rock WP (2004) A multifactorial analysis of factors associated with dental erosion. Br Dent J 196: 283-286. [Crossref]

34. Gandara BK, Truelove EL (1999) Diagnosis and management of dental erosion. $J$ Contemp Dent Pract 1: 16-23. [Crossref]

35. Gruenbaum T (2010) Famous figures in dentistry. Mouth-JASDA 30.

36. Oltramari-Navarro PV, de Almeida RR, Conti AC, Navarro Rde L, de Almeida MR, et al. (2013) Early treatment protocol for skeletal Class III malocclusion. Braz Dent J 24: 167-173. [Crossref]

37. Shnorhokian HI, Chapman DC, Nazif MM, Zullo TG (1984) Cephalometric study of American black children with sickle-cell disease. ASDC J Dent Child 51: 431-433. [Crossref]

38. Lawson W, Patel ZM, Lin FY (2008) The development and pathologic processes that influence maxillary sinus pneumatization. Anat Rec (Hoboken) 291: 1554-1563. [Crossref]

39. Dental Photographs. (2015, September 9). Retrieved November 13, 2016, from Dentodontics: https://dentodontics.com/2015/09/09/angles-classification-ofmalocclusion/

40. (2000) Parameter on plaque-induced gingivitis. American Academy of Periodontology. J Periodontol 71: 851-852. [Crossref]

41. Rada RE, Bronny AT, Hasiakos PS (1987) Sickle cell crises precipitated by periodontal infection: report of two cases. J Am Dent Assoc 114: 799-801. [Crossref]

42. Laurence B, Haywood C Jr, Lanzkron S (2013) Dental infections increase the likelihood of hospital admissions among adults with sickle cell disease. Community Dent Health 30:168-172. [Crossref]

43. Kontakiotis EG, Filippatos CG, Stefopoulos S, Tzanetakis GN (2015) A prospective study of the incidence of asymptomatic pulp necrosis following crown preparation. IntEndod J 48: 512-517. [Crossref]

44. Demirbas Kaya A1, Aktener BO, Unsal C (2004) Pulpal necrosis with sickle cell anaemia. IntEndod J 37: 602-606. [Crossref]

45. Costa CP, Thomaz EB, Souza Sde F (2013) Association between Sickle Cell Anemia and Pulp Necrosis. J Endod 39: 177-181. [Crossref]

Copyright: (C2017 AlDallal SM. This is an open-access article distributed under the terms of the Creative Commons Attribution License, which permits unrestricted use, distribution, and reproduction in any medium, provided the original author and source are credited. 